\title{
Andrew Wiget \\ THE ZUNI STORYTELLING PROJECT: AN EARLY AMERICAN INDIAN EXAMPLE OF TECHNOLOGY IN THE SERVICE OF PRESERVING CULTURAL HERITAGE
}

\begin{abstract}
This presentation reports on the important role played by technology in a multi-year project to document storytelling traditions conducted among the Zuni people, an American Indian tribe. This project had several important results. First, it produced a number of Zuni language radio programs which were broadcast in the native language by the radio station owned by the tribe. These programs played an important role in cultural revitalization. Second, as well as benefitting the Zuni American Indian community, the project recordings also provided professional folklorists new insights into the specific aesthetic dimensions of Zuni storytelling tradition that were previously unknown. And third, the project raised new questions about the use of technology to document cultural heritage, that had a significant impact on our subsequent work, both in the United States and in Siberia.

Keywords: American Indian, storytelling, video recording, radio, native language, restoration.
\end{abstract}

This report discusses several related projects at the Pueblo of Zuni that explored the early use of technology in documenting American Indian storytelling performances and making those performances available not just as texts but as performances to both the host community and professional scholars. In the mid-1980s, the professional standard for folklore documentation was still primarily audio technology. Recorded texts were then transcribed and the transcriptions analyzed for content. Video was primarily supplementary documentation, and used principally to document craft traditions not verbal traditions. Performance theory [1] was just emerging and encouraged a few of us to begin to use video not just to provide texts but to document and analyze performances. Some anthropologists, including Dennis Tedlock, who worked at Zuni, following the early example of noted linguist, Dell Hymes, experimented with "ethnopoetics" a way of transcribing texts that tried to capture textually pauses, volume, timbre and other elements of an actual narrative performance [2-6].

In 1985 I established The New Mexico Heritage Center at New Mexico State University to document the state's folklore traditions. Because of my previous work, the Center was especially committed to assisting American Indian communities in the preservation of the cultural and historical heritage, by providing assistance in project development, including grant writing; technical assistance; professional expertise; training and skills transfer. While I later came to be involved with many tribes, Navajo and Apache., the Indian tribe the Heritage Center was most extensively engaged with the Pueblo of Zuni. My goal was always to train specialists within tribes to develop their own cultural heritage programs [7].

This presentation reports on a multi-year, multi-dimensional project to document storytelling traditions conducted among the Zuni people, an American Indian tribe. 
ZUNI is one of the 567 Federally-recognized tribes 326 of them, including Zuni, have their own reservations. Historically they lived in villages, so the Spanish called such village Indians, "Pueblos". The Zuni reservation is on its traditional homeland. Like many Indian tribes it has its own elected government, answerable only to the Federal government, which makes laws for its people and manages its lands, and a multimillion dollar budget composed of US government treaty obligations and money from its own natural resources [8-12]. In the mid-1980s, Zuni was home to about 9000 people, about 6500 of them members of the tribe. Many worked in salaried jobs in the tribal government. Quite a few Zuni had college degrees. Zuni. As a group the Zuni were becoming integrated into American consumer society. Nevertheless, clan membership, initiation, and religion/tradition still were hugely important. At Zuni, Ritual Knowledge was considered real wealth, and Religious Status real power [13]. The Pueblo had a reputation for remaining a very conservative, inward-turning, closed society in which tribal government was both paralleled and often overruled by traditional religious structures $[14,15]$.

But it was clear to the Zuni themselves that they were having difficulties conserving their traditions. The difference between an elder generation, fluent in Zuni and knowledgeable of Zuni traditions and a youth generation nurtured as much on American mass culture and public schools was huge. Many elders felt out of touch with the youth and grieved for the apparent loss of values. That gap could not be bridged by the middle, parental generation. That middle, or Parental generation, had often been educated away from Zuni language and values in boarding schools, and were fluent only in conversational, not ritual/literary Zuni language. Many of them were only slightly more informed than their children. Our common goal was to find a way to reach all of Zuni and get them engaged in and talking about the Zuni values in traditional stories and the "old words" of the Zuni literary language.

This project, Telapnaawe-Zuni Verbal Art in Performance, was the largest single storytelling project in over 20 years at Zuni. It had many partners, including Zuni Tribal Government, the New Mexico Heritage Center at New Mexico State University, KSHI-FM, Zuni Tribal radio Station. Zuni Public School District Administration, Zuni Pueblo Senior Citizens Center, the American Folklife Center of the Library of Congress, and multiple funding agencies, including the National Endowment for the Arts, National Endowment for the Humanities. and the Library of Congress. The relationship between all the participants was governed by formal Memoranda of Agreement and Contracts signed by University, Tribe and Funding agencies defining the scope of work, the conditions of work, restrictions on reproduction and publication, permissions, and exact accounting of monies.

Funded by a sizeable grant of $\$ 56,000$ from the National Endowment for the Arts, an agency of the United States government, the Heritage Center recorded 15 individual storytellers, four of whom were women, who represented the elders of the last generation of Zuni storytelling. These recordings were meticulously transcribed and translated. Then we transformed them into Zuni language radio programming. The Zuni tribe has its own low power FM radio station, KSHI-FM, which broadcasts during the day and evening. Mostly they play music but local news, announcements of events and other matters of tribal interest are broadcast live in Zuni language. They were excited to cooperate with us in developing cultural radio programming. So we took our recordings, edited them for length (many had to be divided into two parts), and we framed them with traditional Zuni flute 
music and Zuni introduction and credits. In the end, we produced 19 half-hour Zuni language radio programs that were broadcast over the Pueblo's radio station during the most sacred midwinter season, which is the traditional time for storytelling. We were told that at 10:30 AM every office radio in the community was turned on and tuned it. It was enormously popular, and reached across generations. People talked about the nuances of meanings of individual words they had never heard before or about the motives and morality of characters or the consequences of their actions. Following the broadcasts, a survey was taken at Zuni High School in which students reported that their most urgent need-greater than drug education or anything else - was to learn more about Zuni culture. They wanted more. A supplementary grant enabled us to produce an additional 9 radio programs. These 19 radio programs were played during the winter ritual season every year for the next five or six years. Two projects then flowed directly from the Telapnaawe Project.

First, because Zuni storytelling performance is so dynamic, it was thought beneficial to videotape these stories and subtitle them in English (Zuni storytelling language is very complex and not readily accessible to the average Zuni youngster). As a result we wrote a separate grant to make additional video and to study the dynamics of storytelling performance. Zuni storytelling has been well documented, but exploring the folklore performance through video recording suggested several new lines inquiry. The audio recording of the stories made possible the Zuni language radio programs. It also revealed several stylistic features previously not mentioned by folklorists:

modulation of sound quality by manipulating a number of paralinguistic features (tempo, volume, shifting accents, lengthened syllables, rhythmic pausing

a distinctive narrative pattern which I called "sentence chaining" in which the independent clause of one sentence becomes the dependent clause in the next sentence

Simultaneous VHS video recording made possible a performance analysis of stylistic features not previously observed in Zuni storytelling:

Especially important were stylistic differences in gestures,

The existence of a previously unknown set of iconic, stereotyped gestures which are available as an aesthetic resource for Zuni storytelling

Interestingly, neither the artistic manipulation of voice not the existence of a set of iconic, stereotyped gestures for storytelling would have been discovered if folklorists had relied only on transcribed texts.

Second, and more importantly, during the course of these storytelling, the project team located an invaluable treasure: a vast collection of 238 old reel-to-reel tapes recorded during 1966. The collection, totaling more than 400 hours of material, represented the stories of 19 individuals, who by then had all passed away, an entire generation's legacy. Unfortunately, the original acetate tapes, by then already 25 years old, were deteriorating and practically unusable. The Heritage Center, with the Tribe, wrote a contract with the Archive of Folk Culture of the Library Congress, who would acquire and preserve the original tapes; the purchase price would be used to remaster the tapes on new, long-lived Mylar tape as well as make cassette use-copies. Additional monies came from a grant from the National Endowment for the Arts. In 1996 the remastered reel-to-reel tapes and cassette use sets were presented to the Pueblo. Thus was preserved an entire generation's legacy-238 reel-to-tapes preserved more than 800 traditional stories, community leg- 
ends, and folktales totaling more than 400 recorded hours told in the tribal language by 19 Zuni community elders., some of whom were then more than 100 years old. As of 2004, this legacy is now being digitized for use in the Pueblo of Zuni.

The attention to detail provided by combining technology with contemproary folkloristic theory and best practices provided opportunities to extend and deepen our involvement with and service to not only the Pueblo of Zuni but to American Indian tribes and to the professional world. At that time many tribes were engaged in legal battles with governments and private corporations about compensation for historical hardships, and one of the key questions in all legal proceedings, which often depended on written documents, was whether historical memory of American Indians handed down across several generations had any validity because it had no documentary corroboration. Analyses of Zuni verbal art in part made during these projects contributed to a better understanding generally of the nature of American Indian oral traditions and the relationship between aesthetic form and historical validity. They also helped to validate the role of American Indian oral tradition as legal testimony even when oral tradition is not supported by documentary evidence. As a result, we were called upon to provide expert testimony on the validity of oral histories used in evidence in tribal claims cases. These findings played an important role in Zuni's successful lawsuits against the US government.

Conclusion. THE TELAPNA:WE STORYTELLING PROJECTS may seem old-fashioned now. After all, they are a bit of history from 30 years ago. But project had several important results.

First, it produced a number of Zuni language radio programs which were broadcast in the native language by the radio station owned by the tribe. These programs played an important role in cultural revitalization.

Second, as well as benefitting the Zuni American Indian community, the project recordings also provided professional folklorists new insights into the specific aesthetic dimensions of Zuni storytelling tradition that were previously unknown.

Third, analyses of Zuni verbal art made in these projects contributed to a better understanding generally of the nature of American Indian oral traditions and the relationship between aesthetic form and historical validity and played an important role in Zuni's successful lawsuits against the US government.

More important, this early, successful use of technology to document cultural heritage had a significant impact on our subsequent work, both in the United States and in Siberia.

First. GIS mapping of sacred sites and traditional land use in 1995-2000 [16] and Second, the development and use of a community media center, sponsored by the UNESCO's Moscow Office of Information Technology, to document the Yugan Khanty Bear Ceremony [17].

Arguably, the best use of technology is to empower the local community to document and preserve its own traditions.

\section{References}

1. Bauman R. Verbal Art as Performance. Long Grove, IL, USA : Waveland Press, 1984.

2. Hymes D.H. Toward linguistic competence. Working Papers in Sociolinguistics. 1973. № 16.

3. Hymes D.H. Ways of speaking // Explorations in the ethnography of speaking / Bauman R., Sherzer J. (Eds.). Cambridge : Cambridge University Press, 1976. P. 433-452. 
4. Hymes D.H. Discovering oral performance and measured verse in American Indian narrative // New Literary History. 1976. Vol. 8. P. 431-457. DOI: 10.2307/468294

5. Tedlock D. Finding the Center: Narrative Poetry of the Zuni Indians. Lincolon : University of Nebraska Press, 1972.

6. Wiget A. Telling the Tale: A Performance Analysis of A Hopi Coyote Story // Recovering the Word: Essays on Native American Literature / eds. B. Swann, A. Krupat. Berkeley : U of California, 1987. P. 291-336.

7. Dyal S. Preserving raditional arts : a toolkit for Native American communities. Los Angeles : UCLA American Indian Studies Center, 1985.

8. EagleWoman A. (Wambdi A. WasteWin). The Bureau of Indian Affairs and Reservations. Vol 2: Indians In Contemporary Society, ed. G. Bailey. Handbook of North American Indians. (17 vol.) / Ed. W.C. Sturtevant. Washington, D.C. : Smithsonian Institution, 2008. P. 86-96.

9. Thornton R. United States Native Population. Vol. 2: Indians In Contemporary Society, ed. G. Bailey. Handbook of North American Indians (17 vol.) / Ed. W.C. Sturtevant. Washington, D.C. : Smithsonian Institution, 2008. P. 269-274.

10. Crampton C.G. The Zunis of Cibola. Salt Lake City : University of Utah Press. 1977.

11. Woodbury R. Zuni Prehistory and History to 1850. Vol. 9: Southwest. ed. A. Ortiz. Handbook of North American Indians (17 vol.) / Ed. W.C. Sturtevant. Washington, D.C. : Smithsonian Institution, 1979. P. 467-473.

12. Eggan F. and T.N. Pandey. Zuni History, 1850-1970. Vol. 9: Southwest, ed. A. Ortiz. Handbook of North American Indians (17 vol.) / Ed. W.C. Sturtevant. Washington, D.C. : Smithsonian Institution, 1979. P. 474-481.

13. Stevenson M.C. The Zuni Indians. Their Mythology, Esoteric Fraternities, and Ceremonies // Annual Report of the Bureau of American Ethnology. 1905. № 23.

14. Frank H. Cushing, Outlines of Zuni Creation Myths // Annual Report of the Bureau of Ethnology. Washington, D.C. : U.S. Govt. Printing Office, 1896. № 13.

15. Frank Hamilton Cushing. Zuni Folk Tales. New York ; London : G.P. Putnam's Sons, 1901.

16. Wiget A., Balalaeva $O$. Khanty, people of the taiga: surviving the twentieth century. University of Alaska Press, 2011. P. 103-141.

17. Яун-ях - община коренных малочисленных народов Севера [Электронный ресурс] / Наша культура. URL: http://yaoun-yakh.ru/ (дата обращения: 04.09.2019).

Andrew Wiget, professor, professor Emeritus, New Mexico State University (USA).

E-mail: andrew.wiget@gmail.com

Vestnik Tomskogo gosudarstvennogo universiteta. Kul'turologiya i iskusstvovedeniye - Tomsk

State University Journal of Cultural Studies and Art History, 2019, 36, pp. 259-264.

DOI: $10.17223 / 22220836 / 36 / 25$

THE ZUNI STORYTELLING PROJECT: AN EARLY AMERICAN INDIAN EXAMPLE OF TECHNOLOGY IN THE SERVICE OF PRESERVING CULTURAL HERITAGE

Keywords: American Indian; folklore; video recording; radio; native language; heritage preservation; digital humanities.

The emergence of a new trend known in America as "digital humanities" is having a great effect upon research and teaching. Digital humanities makes available not only the resources of the internet, but the possibility to reproduce documents with a resolution high enough to distinguish important paleographic characteristics, rotate and view an object in all dimensions, and even create virtual tours of historic sites. But these developments, which we now take for granted, emerged from a long tradition of trying to adapt technology to the preservation of cultural heritage.

Historically, folklorists worked with texts, at first simply transcribed by hand, but then transcribed from recordings. By the 1970s, transistorized electronics made handheld audiotape cassette recorders possible. Video was the rather poor quality VHS recordings, while the laptop was not even a dream in Bill Gates' head. This is the historical context in which we began to explore different ways to exploit old technologies.

This presentation reports on the important role played by technology in a multi-year project to document storytelling traditions conducted among the Zuni people, an American Indian tribe of 9000 people living in my home state of New Mexico. This project had several important results. First, it produced a number of Zuni language radio programs which were broadcast in the native Zuni language by the radio station owned by the tribe. These programs played an important role in cultural revitalization, and became the subject of conversation throughout the community. Second, as well as benefitting 
the Zuni American Indian community, the project recordings, especially video recordings, also provided professional folklorists new insights into the specific aesthetic dimensions of Zuni storytelling tradition that were previously unknown, though Zuni has a long history as the subject of anthropological and folkloric research. And third, the project raised new questions about the use of technology to document cultural heritage, especially the intergenerational differences in attitudes towards and uses of technology, that had a significant impact on our subsequent work, both in the United States and in Siberia.

\section{References}

1. Bauman, R. (1984) Verbal Art as Performance. Long Grove, IL, USA: Waveland Press.

2. Hymes, D.H. (1973) Toward linguistic competence. Working Papers in Sociolinguistics.

3. Hymes, D.H. (1976) Ways of speaking. In: Bauman, R. \& Sherzer, J. (eds) Explorations in the Ethnography of Speaking. Cambridge: Cambridge University Press. pp. 433-452).

4. Hymes, D.H. (1976) Discovering oral performance and measured verse in American Indian narrative. New Literary History. 8. pp. 431-457. DOI: 10.2307/468294

5. Tedlock, D. (1972) Finding the Center: Narrative Poetry of the Zuni Indians. Lincolon: University of Nebraska Press.

6. Wiget, A. (1987) Telling the Tale: A Performance Analysis of A Hopi Coyote Story. In: Swann, B. \& Krupat, A. (eds) Recovering the Word: Essays on Native American Literature. Berkeley: University of California Press. pp. 291-336.

7. Dyal, S. (1985) Preserving traditional arts: a toolkit for Native American communities. Los Angeles: UCLA American Indian Studies Center.

8. EagleWoman, A. (2008) The Bureau of Indian Affairs and Reservations. In: Bailey, G. (ed.) Indians in Contemporary Society. Washington, D.C.: Smithsonian Institution. pp. 86-96.

9. Thornton, R. (2008) United States Native Population. In: Bailey, G. (ed.) Indians in Contemporary Society. Washington, D.C.: Smithsonian Institution. pp. 269-274.

10. Crampton, C.G. (1977) The Zunis of Cibola. Salt Lake City: University of Utah Press.

11. Woodbury, R. (1979) Zuni Prehistory and History to 1850. In: Ortiz, A. (ed.) Southwest. Washington, D.C.: Smithsonian Institution. pp. 467-473.

12. Eggan, F. and Pandey, T.N. (1979) Zuni History, 1850-1970. In: Ortiz, A. (ed.) Southwest. Washington, D.C.: Smithsonian Institution. pp. 474-481.

13. Stevenson, M. C. (1905) The Zuni Indians. Their Mythology, Esoteric Fraternities, and Ceremonies. Annual Report of the Bureau of American Ethnology. 23.

14. Cushing, F.H. (1896) Outlines of Zuni Creation Myths. Annual Report of the Bureau of Ethnology. 13.

15. Cushing, F.H. (1901) Zuni Folk Tales. New York, London: G.P. Putnam's Sons

16. Wiget, A. \& Balalaeva, O. (2011) Khanty, People of the Taiga: Surviving the Twentieth Century. University of Alaska Press. pp. 103-141.

17. Yaoun-yakh.ru. (n.d.) Yaoun-yah - a community of indigenous peoples of the North [Online] Available from: http://yaoun-yakh.ru/ (Accessed: 4th September 2019). 